\title{
Komunitas Parasitoid Lalat Pengorok Daun pada Pertanaman Sayuran Dataran Tinggi
}

\author{
Rusli Rustam ${ }^{* *}$, Aunu Rauf2), Nina Maryana2), Pudjianto2), Dadang2) \\ 1*)Program Studi Hama dan Penyakit Tanaman, Jurusan Agronomi \\ Fakultas Pertanian, Universitas Riau Pekanbaru \\ 2)Departemen Proteksi Tanaman, Fakultas Pertanian \\ Institut Pertanian Bogor \\ Diterima 10-03-2008 Disetujui 15-09-2008
}

\begin{abstract}
Leafminer fly, Liriomyza spp. are widely known as new important pests attacking many vegetable species in high land in Indonesia. The objective of the research was to study community of parasitoid leafminer in high altitude, and parasitization level. This research also looked at more specific on parasitization level caused by Opius chromatomyiae. There were four species of leafminer recorded from the survey, Liriomyza huidobrensis, Liriomyza sativae, Liriomyza chinensis and Chromatomyia horticola. The observation also found eight species of parasitioid associated with collected leafminers. Six species of recorded parasitoid belonged to family of Eulopidae, and two rest species belonged to Braconidae and Eucoilidae respectively. Those eight species of parasitoids were Hemiptarsenus varicornis, Asecodes deluchii, Neochrysocharis okazakii, Neochrysocharis formosa, Neocrhysocharis sp. Quadrastichus liriomyzae, Opius chromatomyaie, Gronotoma micromorpha. Parasitoid Opius chromatomyiae and Hemiptarsenus varicornis were found to be dominant in the range altitude between 1001-1300 and 1301-1600 asl. From 16 spesies of hosts attacked by leaf miners, only Opius chromatomyiae was recorded to have ability to parasitize the leafminer in 13 host species with parasitization level reached 1,84$62,26 \%$.
\end{abstract}

Keywords: Liriomyza spp, parasitoid, Opius chromatomyiae,

\section{PENDAHULUAN}

Hama lalat pengorok daun Liriomyza spp. merupakan hama utama pada pertanaman sayuran. Sejak ditemukan pertama kali pada tahun 1994 di daerah Cisarua, Bogor (Rauf 1995), hama lalat pengorok daun masih menjadi kendala utama bagi petani, khususnya petani sayuran. Hama ini bersifat polifag dan tingkat serangan hama ini pada pertanaman sayuran dapat menurunkan hasil hingga 30-70\% (Rauf \& Shepard 1999).

Lalat Liriomyza diketahui berasal dari Amerika Serikat dan Amerika Selatan (Rauf 1995). Genus Liriomyza terdiri dari 300 spesies dan tiga spesies yang bersifat polifag yang menimbulkan kerugian di berbagai negara (Spencer \& Steykal 1986). Ketiga spesies tersebut adalah Liriomyza trifolii (Burgess), Liriomyza sativae Blanchard dan Liriomyza huidobrensis (Blanchard). Menurut Rauf (1999),

*Telp: 081319126369

Email: rusli69@yahoo.co.id
Liriomyza huidobrensis merupakan spesies yang pertama kali masuk ke Indonesia.

Aktivitas peneluran dan makan imago serta aktivitas makan larva pengorok daun dapat menyebabkan rusaknya sel-sel jaringan daun tanaman dengan gejala berupa bintik-bintik putih serta liang korokan larva yang berkelok-kelok dan berwarna keperakan. Akibatnya luas bagian daun yang berfotosintesis berkurang sehingga menurunkan kualitas dan kuantitas hasil (Parrella 1987; Cardova \& Karel 1990), menurunkan nilai estetika, menurunkan ketahanan terhadap penyakit, dan daun lebih cepat gugur (Supartha 1998).

Umumnya petani sampai sekarang ini masih mengandalkan aplikasi insektisida dalam mengendalikan lalat pengorok daun. Namun aplikasi insektisida dua kali per minggu dilaporkan belum bisa menekan populasi hama pengorok daun (Rauf 1999). Di samping itu, aplikasi insektisida sering memberikan pengaruh samping yang buruk, seperti terjadinya resistensi pada hama sasaran dan matinya musuh alami (Parella 1982; Jhonson 1993). 
Pengendalian hayati dengan memanfaatkan musuh alami merupakan salah satu strategi PHT yang menawarkan solusi pengendalian hama yang lebih ramah terhadap lingkungan. Beberapa parasitoid yang dilaporkan berasosiasi dengan Liriomyza di antaranya adalah Hemiptarsenus varicornis, Opius chromatomyiae, Asecodes deluchii, Neochrysocharis formosa, Gronotoma micromorpha (Rauf et al, 2000; Susilawati 2002; Purnomo 2003). Tabuhan, Opius chromatomyaie merupakan endoparasitoid yang dilaporkan dominan menyerang lalat pengorok daun (Rustam 2002). Namun sangat disayangkan bahwa pemanfaatan parasitoid ini belum banyak dilakukan karena kajian tentang Opius chromatomyaie ini masih sangat terbatas. Hubungan antara parasitoid dan inanginangnya, serta faktor-faktor lingkungan yang mempengaruhi interaksinya di lapangan, misalnya ketinggian lokasi dan tanaman inang merupakan aspekaspek yang perlu diketahui untuk merumuskan strategi pengendalian hayati yang tepat.

Penelitian ini bertujuan untuk mempelajari komunitas parasitoid lalat pengorok daun pada pertanaman sayuran dataran tinggi serta mengetahui tingkat parasitisasi Opius chromatomiae pada berbagai ketinggian dan jenis tanaman inang.

\section{BAHAN DAN METODE}

Tempat dan Waktu Penelitian. Penelitian dilaksanakan pada pertanaman sayuran di berbagai daerah di Cianjur dan Bogor untuk pengambilan daun tanaman yang terserang lalat pengorok daun (Tabel 1), sedangkan untuk pemeliharaan dan identifikasi lalat pengorok daun dan parasitoidnya dilaksanakan di Laboratorium lapangan Agropolitan, Cianjur dan Laboratorium Ekologi Serangga, Departemen Proteksi Tanaman, Fakultas Pertanian, Institut Pertanian Bogor. Penelitian berlangsung dari Juni sampai Mei 2007.

Pengambilan Contoh Daun. Pengambilan contoh daun dilaksanakan di berbagai daerah di Kabupaten Cianjur dan Bogor. Daun-daun contoh yang memperlihatkan gejala korokan dikumpulkan dari lapangan, masing-maisng berjumlah 20-40 helai daun tergantung ukuran daun. Daun contoh dari tiap tumbuhan kemudian dimasukkan ke dalam kontong plastik dan diberi label tanggal pengambilan dan nama tanaman. Kantong plastik diberi label yang berisi informasi tentang lokasi, tanggal pengambilan daun
Tabel 1. Tempat pengambilan sampel penelitian

\begin{tabular}{|c|c|c|c|}
\hline Kabupaten & Kecamatan & Desa & $\begin{array}{c}\text { Ketinggian } \\
\text { Tempat } \\
\text { (meter dpl) }\end{array}$ \\
\hline \multirow[t]{13}{*}{ Cianjur } & Cipanas & Cimacan & 1074 \\
\hline & & Sindang jaya & $1173-1513$ \\
\hline & & Sindang laya & 903 \\
\hline & & Sukatani & $1203-1600$ \\
\hline & Cugenang & Cibereum & $894-934$ \\
\hline & & Cijedil & 791 \\
\hline & & Nyalindung & 927 \\
\hline & Pacet & Ciherang & $969-1060$ \\
\hline & & Ciloto & $1203-1218$ \\
\hline & & Ciputri & 1069 \\
\hline & & Cipendawa & 1076 \\
\hline & Sukaresmi & Cibadak & $875-974$ \\
\hline & & Kawung luwuh & 834 \\
\hline \multirow[t]{2}{*}{ Bogor } & Cisarua & Batu layang & 903 \\
\hline & & Tugu utara & 980 \\
\hline
\end{tabular}

contoh, umur tanaman, ketinggian tempat dari permukaan laut (dpl) dan kemudian disimpan dalam kotak pendingin untuk selanjutnya dibawa ke laboratorium. Pengukuran ketinggian tempat lokasi diukur dengan menggunakan alat Geographyc Positions System (GPS).

Pengamatan di Laboratorium. Daun contoh yang dikoleksi dari lapangan dibersihkan dari kotoran, kemudian dimasukkan ke dalam wadah plastik (diameter $20 \mathrm{~cm}$, tinggi $30 \mathrm{~cm}$ ). Pada bagian tengah wadah dipasang sekat kawat sebagai penyangga daun, dan bagian atas wadah dibuat ventilasi udara berbentuk bujur sangkar dengan ukuran $15 \times 15 \mathrm{~cm}$. Jenis dan banyaknya lalat pengorok daun dan parasitoid yang muncul diamati setiap hari.

Imago Liriomyza dan spesies parasitoid yang muncul dihitung dan dicatat, kemudian dimasukkan ke dalam botol kecil berisi alkohol 70\% untuk dikoleksi serta diidentifikasi. Selanjutnya dilakukan perhitungan tingkat parasitisasi dengan menggunakan rumus sebagai berikut:

Tingkat Parasitisasi $=$

Jumlah Imago parasitoid yang muncul total banyaknya Liriomyza dan parasitoid yang muncul

Identifikasi. Spesimen imago Liriomyza diidentifikasi berdasarkan ciri morfologi dengan menggunakan kunci determinasi Spencer (1973). 
Proses identifikasi menggunakan mikroskop stereo. Parasitoid diidentifikasi dengan menggunakan Program Lucid Key: Liriomyza Parasitoid of South East Asia (Fisher et al, 2006).

\section{HASIL DAN PEMBAHASAN}

Hasil. Berdasarkan pengumpulan daun contoh yang menunjukkan gejala korokan sebagai tanda terserang oleh lalat pengorok daun di daerah dataran tinggi Kab. Cianjur dan Bogor didapatkan 16 spesies tanaman yang terserang lalat pengorok daun yang terdiri atas sembilan familia tanaman yakni Liliaceae, Cruciferae, Cucurbitaceae, Fabaceae, Umbeliferae, Compositae, Amaranthaceae, Chenopodiaceae dan Solanaceae (Tabel 2). Familia Cruciferae merupakan kelompok tanaman terbesar yang banyak ditanam di dataran tinggi.

Spesies Liriomyza yang muncul dari daun contoh yang terserang Liriomyza bervariasi tergantung jenis tanaman. Dari empat spesies lalat pengorok daun yang diperoleh, dua spesies bersifat polifag yaitu $L$.

Tabel 2. Spesies tanaman yang terserang lalat pengorok daun

\begin{tabular}{|c|c|c|c|}
\hline No. & Nama Indonesia & Nama latin & Familia \\
\hline 1 & Bawang daun & Alium fistolusum & Liliaceae \\
\hline 2 & Brokoli & $\begin{array}{l}\text { Brassica } \\
\text { oleraceae var } \\
\text { botrytis }\end{array}$ & Cruciferae \\
\hline 3 & Caisim & $\begin{array}{l}\text { Brassica } \\
\text { chinensis var } \\
\text { para chinensis }\end{array}$ & Cruciferae \\
\hline 4 & Kubis & $\begin{array}{l}\text { Brassica } \\
\text { oleraceae }\end{array}$ & Cruciferae \\
\hline 5 & Pak coy & $\begin{array}{l}\text { Brassica } \\
\text { chinensis }\end{array}$ & Cruciferae \\
\hline 6 & Caylan & $\begin{array}{l}\text { Brassica } \\
\text { alboglabra }\end{array}$ & Cruciferae \\
\hline 7 & Ketimun & $\begin{array}{l}\text { Cucumber } \\
\text { sativus }\end{array}$ & Cucurbitaceae \\
\hline 8 & Oyong & Luffa acutangula & Cucurbitaceae \\
\hline 9 & Kacang kapri & Pisum sativum & Fabaceae \\
\hline 10 & Buncis & $\begin{array}{l}\text { Phaseolus } \\
\text { vulgaris }\end{array}$ & Fabaceae \\
\hline 11 & Seledri & $\begin{array}{l}\text { Apium } \\
\text { graveolens }\end{array}$ & Umbeliferae \\
\hline 12 & Selada & Lactuca sativa & Compositae \\
\hline 13 & Tang och & Lactuca sp. & Compositae \\
\hline 14 & Bayam & Amaranthus spp. & Amaranthaceae \\
\hline 15 & Horinso & $\begin{array}{l}\text { Spinocia } \\
\text { oleracea }\end{array}$ & Chenopodiaceae \\
\hline 16 & Tomat & $\begin{array}{l}\text { Solanum } \\
\text { lycopersicum }\end{array}$ & Solanaceae \\
\hline
\end{tabular}

huidobrensis dan L. sativae. Kedua spesies ini dapat menyerang lebih dari satu spesies tanaman (Tabel 3). Dua spesies lainnya, L. chinensis dan Chromatomyiae horticola, merupakan spesies yang monofag yang menyerang masing-masing tanaman bawang daun dan kacang kapri.

Berdasarkan ketinggian tempat yang diukur dengan menggunakan GPS, spesies L. huidobrensis mendominasi semua daerah, sedangkan $L$. sativae dan L. chinensis lebih banyak ditemukan pada daerah dengan ketinggian yang lebih rendah (Gambar 1).

Pada pengamatan di lapangan, bawang daun merupakan tanaman yang dominan pada pertanaman sayuran dataran tinggi di Kab. Cianjur dan mendapat serangan lalat Liriomyza yang tinggi tingkat serangannya. Dari pengamatan tambahan, dengan mengamati jumlah spesies yang menyerang bawang daun, ternyata satu helai daun bawang dapat diinfasi oleh dua spesies Liriomyza (Tabel 4). Kedua spesies yang menyerang tanaman bawang daun tersebut adalah L. huidobrensis dan L. chinensis dengan jumlah larva yang muncul dari daun korokan berturut-turut 19,02 dan 1,12 ekor/daun. Parasitoid yang muncul dari korokan daun adalah $H$. varicornis dan $O$. chromatomyiae dengan tingkat parasitisasi masing-masing $8,81 \%$ dan $3,11 \%$.

Jenis parasitoid, kelimpahan, dan tingkat parasitisasi. Hasil survei yang dilakukan pada berbagai jenis sayuran yang terserang lalat pengorok daun, menunjukkan bahwa terdapat delapan spesies parasitoid yang berassosiasi dengan lalat pengorok daun yang terdiri atas tiga familia (Tabel 5). Ketiga familia tersebut adalah Eulopidae, Braconidae, dan Eucoilidae. Dari delapan spesies yang ditemukan enam

Tabel 3. Spesies lalat pengorok daun pada berbagai jenis tanaman inangnya

\begin{tabular}{cll}
\hline No. & $\begin{array}{l}\text { Spesies lalat } \\
\text { pengorok daun }\end{array}$ & \multicolumn{1}{c}{ Tanaman inang } \\
\hline 1. & L. huidobrensis & $\begin{array}{l}\text { Bawang daun, brocoli, buncis, } \\
\text { caisim, caylan, horinso, kacang } \\
\text { kapri, ketimun, kubis, pak coy, } \\
\text { selada, oyong, seledri, tang och, } \\
\text { tomat }\end{array}$ \\
2. & L. sativae & $\begin{array}{l}\text { Buncis, kacang kapri, ketimun, pak } \\
\text { coy, tomat } \\
\text { Bawang daun }\end{array}$ \\
3. & L. chinensis & Kacang kapri
\end{tabular}


Tabel 4. Kelimpahan dan spesies Liriomyza dan parasitoid per daun pada tanaman bawang daun

\begin{tabular}{|c|c|c|}
\hline Parameter & $\begin{array}{l}\text { Rerata dan } \\
\text { kisaran jumlah } \\
\text { per daun }\end{array}$ & $\begin{array}{l}\text { Rerata dan } \\
\text { kisaran } \\
\text { persentase } \\
\text { parasitisasi } \\
\text { parasitoid (\%) }\end{array}$ \\
\hline $\begin{array}{l}\text { Pupa } \\
\text { Jenis Liriomyza }\end{array}$ & $26,13(7-48)$ & - \\
\hline Liriomyza huidobrensis & $19,02(4-39)$ & - \\
\hline $\begin{array}{l}\text { Liriomyza chinensis } \\
\text { Jenis parasitoid }\end{array}$ & $1,12(0-7)$ & - \\
\hline $\begin{array}{l}\text { Hemiptarssenus } \\
\text { varicornis }\end{array}$ & $1,6 \quad(0-7)$ & $8,81 \quad(0-42,86)$ \\
\hline Opius chromatomyiae & $0,67 \quad(0-4)$ & $3,11(0-13,64)$ \\
\hline
\end{tabular}

Tabel 5. Kelompok parasitoid yang menyerang lalat pengorok daun

\begin{tabular}{lll}
\hline No. & \multicolumn{1}{c}{ Familia } & \multicolumn{1}{c}{ Spesies } \\
\hline 1 & Eulopidae & $\begin{array}{l}\text { Hemiptarsenus varicornis, } \\
\text { Asecodes deluchii, } \\
\end{array}$ \\
& & Neochrysocharis okazakii, \\
& & Neochrysocharis formosa, \\
& & Neocrhysocharis sp., \\
& & Quadrastitchus liriomyzae \\
& & Opius chromatomyaie \\
3 & Eraconidae & Gronotoma micromorpha \\
\hline
\end{tabular}

$\square$ L.huidobrensis $\square$ L. chinensis $\quad \square$ L. sativae $\quad \square$ C.horticola

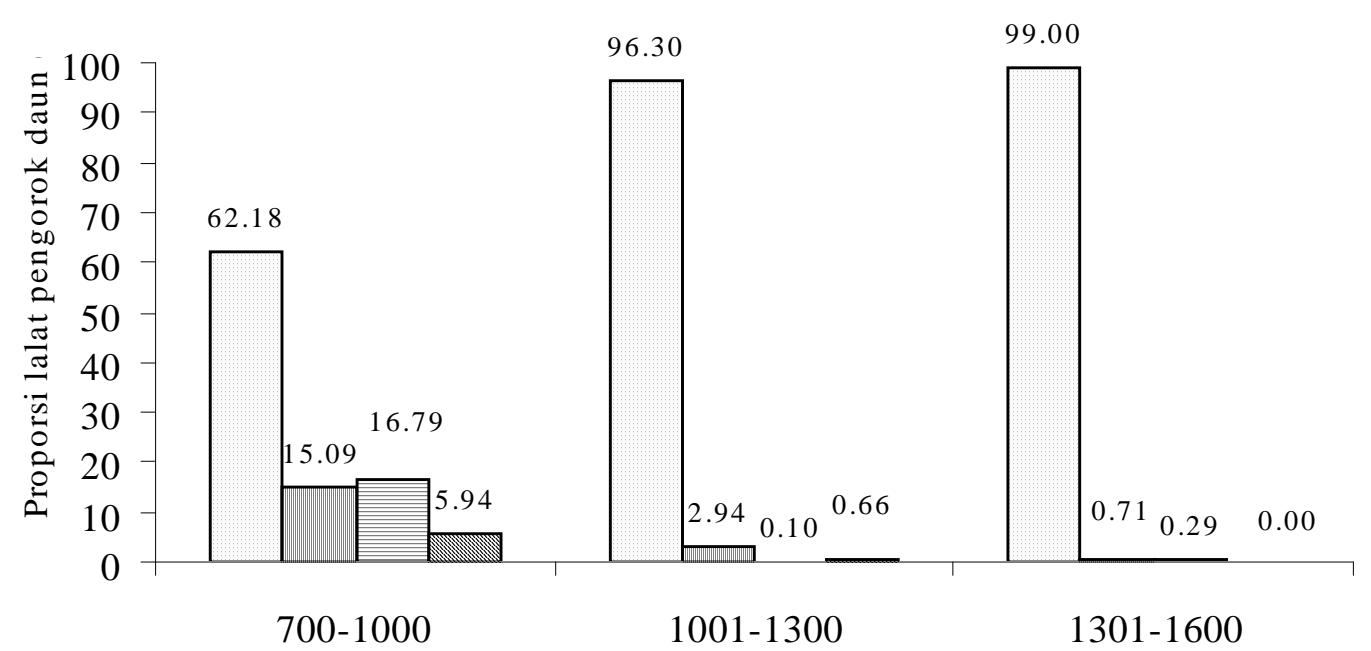

Ketinggian tempat (dpl)

Gambar 1. Komposisi lalat pengorok daun menurut ketinggian tempat

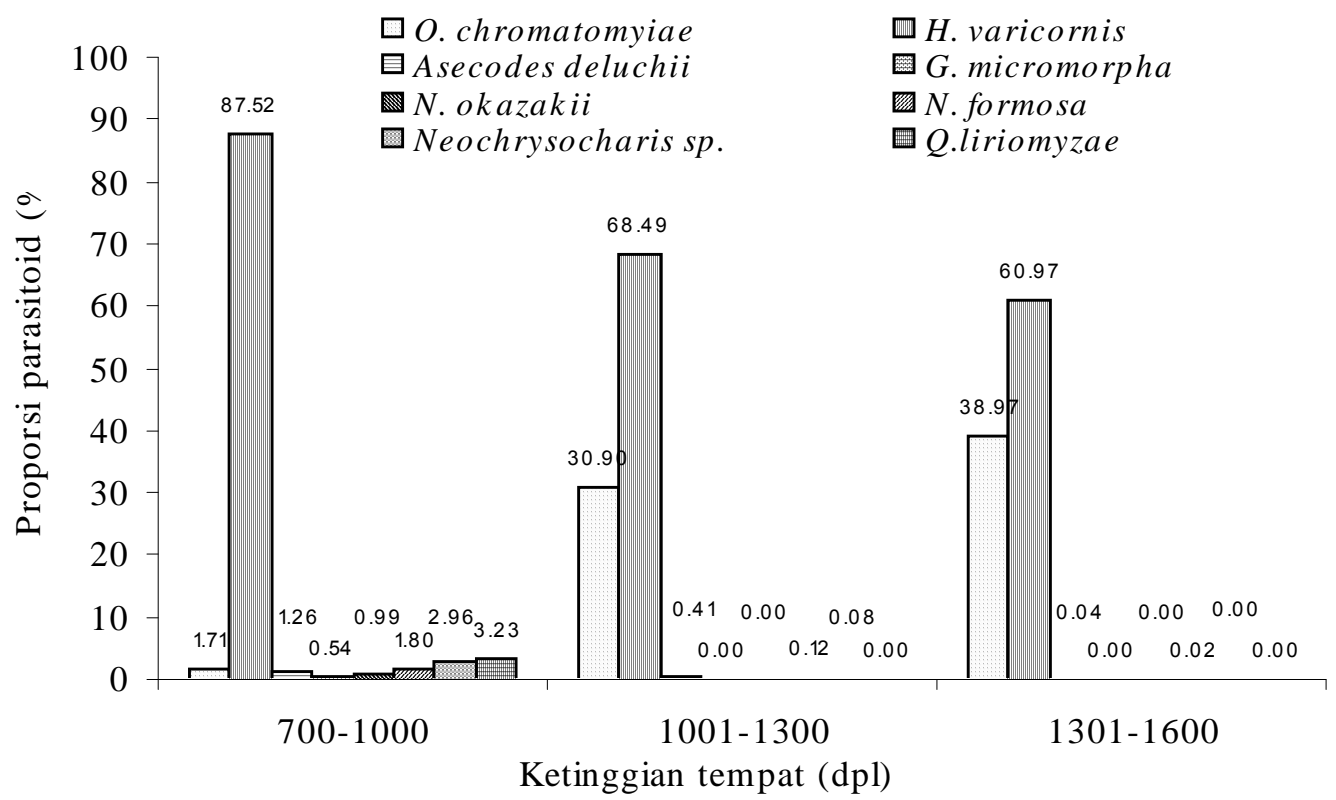

Gambar 2. Komposisi parasitoid menurut ketinggian tempat 
Tabel 6. Tingkat serangan, kelimpahan lalat pengorok dan tingkat parasitisasi parasitoid pada berbagai jenis tanaman inang

\begin{tabular}{|c|c|c|c|c|c|c|}
\hline No. & $\begin{array}{l}\text { Tanaman } \\
\text { inang }\end{array}$ & $\begin{array}{l}\text { Jml. } \\
\text { daun }\end{array}$ & $\begin{array}{c}\text { Tingkat } \\
\text { serangan }\end{array}$ & $\begin{array}{c}\text { Total } \\
\text { lalat } \\
\text { pengorok }\end{array}$ & Total parasitoid & $\begin{array}{c}\text { Parasitisasi } \\
\text { parasitoid } \\
(\%)\end{array}$ \\
\hline 1. & Bw. daun & 2050 & 89,39 & 6500 & 2997 & 31,56 \\
\hline 2. & Brocoli & 120 & 100 & 3012 & 1625 & 35,04 \\
\hline 3. & Caisim & 20 & 10,00 & 183 & 162 & 46,96 \\
\hline 4. & Kubis & 20 & 100 & 45 & 3 & 6,25 \\
\hline 5. & Pak coy & 40 & 60,05 & 117 & 14 & 10,69 \\
\hline 6. & Caylan & 120 & 96,67 & 3533 & 443 & 11,14 \\
\hline 7. & Ketimun & 180 & 93,00 & 3163 & 944 & 22,94 \\
\hline 8. & Oyong & 10 & 100 & 13 & 6 & 31,58 \\
\hline 9. & Kc. kapri & 180 & 100 & 1130 & 529 & 31,89 \\
\hline 10 & Buncis & 60 & 97,50 & 155 & 51 & 24,76 \\
\hline 11. & Seledri & 280 & 55,00 & 400 & 123 & 23,52 \\
\hline 12. & Selada & 20 & 9,00 & 171 & 290 & 62,91 \\
\hline 13. & Tang och & 80 & 100 & 133 & 87 & 39,55 \\
\hline 14. & Bayam & 38 & 15,00 & 7 & 8 & 53,33 \\
\hline 15. & Horinso & 140 & 90,00 & 721 & 916 & 55,96 \\
\hline 16. & Tomat & 100 & 82,20 & 898 & 502 & 35,86 \\
\hline
\end{tabular}

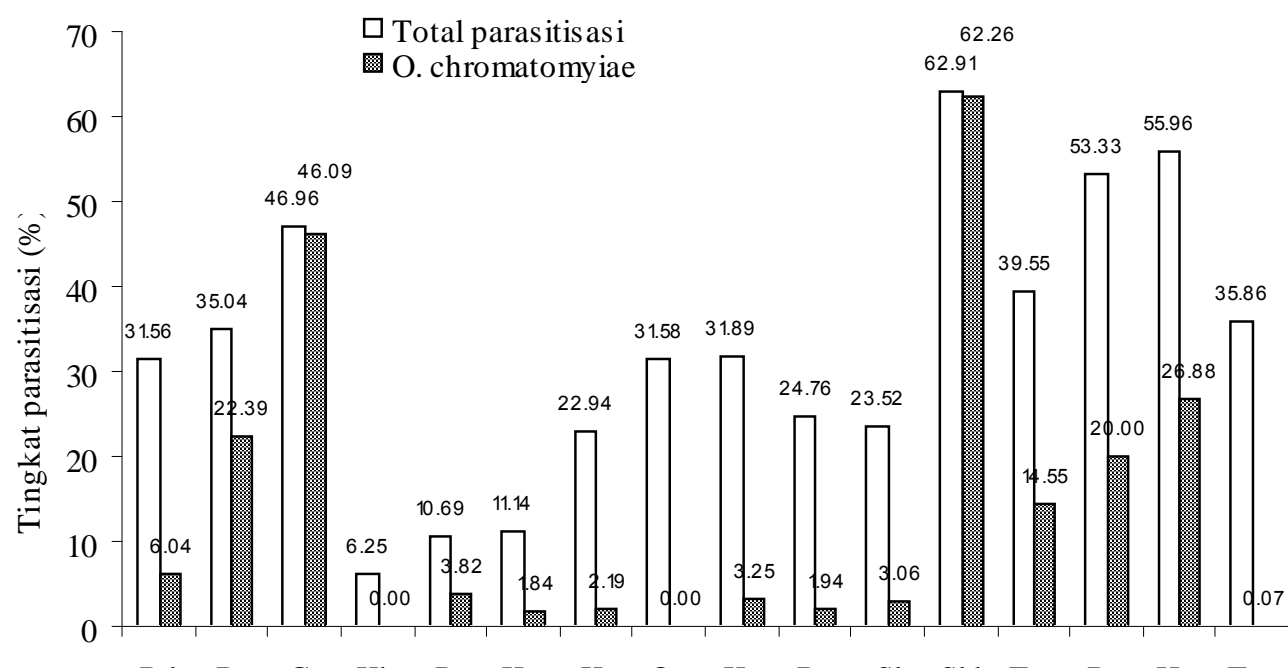

$\begin{array}{llllllllllllllll}\mathrm{Bd} & \mathrm{Br} & \mathrm{Cs} & \mathrm{Kb} & \mathrm{Pc} & \mathrm{Ky} & \mathrm{Kt} & \mathrm{Oy} & \mathrm{Kc} & \mathrm{Bc} & \mathrm{Sl} & \mathrm{Sld} & \mathrm{Toc} & \mathrm{By} & \mathrm{Hrs} & \mathrm{Tmt}\end{array}$

Tanaman inang

Ket. Bawang daun (Bd), Brocoli (Br), Caisim (Cs), Kubis (Kb), Pak coy (Pc), Kaylan (Ky), Ketimun (Kt), Oyong (Oy), Kacang kapri (Kc), Buncis (Bc), Seledri(SI), Seleda (Sld), Tang och (Toc), Bayam (By), Horinso(Hrs), Tomat (Tmt)

Gambar 3. Tingkat parasitisasi parasitoid dan O. chromatomyiae

spesies adalah Eulophidae, dan masing-masing satu spesies dari familia Braconidae dan Eucoilidae.

Kelimpahan parasitoid tersebut pada berbagai ketinggian yang di bagi atas tiga daerah ketinggian $700-$ 1000, 1001-1300 dan 1301-1600 m di atas permukaan laut (dpl), terlihat bahwa $H$. varicornis merupakan spesies parasitoid yang mendominasi di semua ketinggian daerah. Spesies O. chromatomyiae banyak ditemukan pada ketinggian 1001-1300 dan 1301-1600 $\mathrm{m}$ dpl namun populasinya masih rendah dibandingkan H. varicornis. (Gambar 2).
Semakin tinggi ketinggian tempat dari permukaan laut, proporsi $O$. chromatomyaie semakin meningkat. Sedangkan proporsi $H$. varicornis semakin menurun dengan meningkatnya ketinggian tempat dari permukaan laut.

Tingkat parasitisasi parasitoid berkisar 6,25 $62,91 \%$ untuk total semua parasitoid dan 1,84-62,26\% untuk $O$. chromatomyiae dengan tingkat serangan serangan lalat pengorok daun $15-100 \%$. O. chromatomyiae dapat menyerang lalat pengorok daun yang menginfasi semua spesies tanaman yang dikoleksi (Tabel 6). Tingkat parasitisasi tertinggi terjadi 
pada tanaman selada dengan angka 62,26\% (Gambar 3).

\section{PEMBAHASAN}

Dari hasil penelitian ini ditemukan empat spesies dari lalat pengorok daun yang menyerang tanaman sayuran di dataran tinggi Kab Cianjur dan Bogor. $L$. huidobrensis dicacat sebagai spesies lalat pengorok daun yang banyak menyerang berbagai jenis tanaman sayuran. Lalat pengorok daun spesies $L$. huidobrensis bersifat polifag (Parella 1987; Murphy \& LaSalle 1999). Rauf et al, (2000), melaporkan bahwa L. huidobrensis dapat menyerang 70 spesies tanaman yang tergolong ke dalam 20 famili. Banyaknya tanaman inang memungkinkan $L$. huidobrensis dengan cepat dan leluasa memencar dari satu wilayah ke wilayah lain (Setiawati 1998).

L. huidobrensis merupakan spesies yang pertama kali ditemukan di Indonesia pada dataran tinggi (Rauf 1999). Dari hasil penelitian, ditemukan spesies $L$. huidobrensis sangat mendominasi di daerah ketinggian. Semakin tinggi ketinggian tempat dari permukaan laut, proporsi populasi L. hudobrensis semakin meningkat. Pada skala ketinggian 1000-13001 proporsi $L$. huidobrensis sebesar $96,30 \%$ dan skala 1301-1600 proporsinya meningkat menjadi $99 \%$.

Lalat pengorok spesies $L$. sativae lebih banyak pada skala ketinggian yang lebih rendah, yakni skala 700-1000 m dpl dan menyerang berbagai jenis tanaman, namun kisaran tanaman inangnya lebih sempit dibandingkan L. huidobrensis. L. sativae juga bersifat polifag dan banyak menyerang sayuran pada dataran rendah (Rauf 1999; Susilawati 2002; Herlinda et al, 2006). Kerusakan pada tanaman ketimun di dataran rendah dapat mencapai 60\% (Rauf \& Shepar 2001).

L. chinensis hanya ditemukan menyerang tanaman bawang daun. Hal ini menunjukkan L. chinensis berifat monofag dan ditemukan pertama kali di daerah Brebes (Jawa Tengah), bahkan outbreak serta menyebabkan kehilangan hasil yang begitu tinggi dan banyak menyerang tanaman bawang dataran rendah (Rauf \& Shepard 2001). L. chinensis dapat beradaptasi terhadap tanaman inang dengan cepat. L. chinensis telah dapat beradaptasi dengan tanaman bawang daun yang tumbuh pada ketinggian di atas $1301 \mathrm{~m}$ dpl. Namun proporsinya masih rendah yaitu sebesar $0,29 \%$ dibandingkan dengan proporsinya pada skala ketinggian 700-1000 m dpl yakni sebesar 16,79\%.
Kemampuam L. chinensis beradaptasi dengan dataran tinggi dapat membuat kerusakan tanaman bawang daun semakin parah. Dari survey yang dilakukan, tingkat serangan $L$. chinensis, lalat pengorok daun ini mencapai $100 \%$. Pengamatan intensif terhadap tanaman daun bawang dengan melihat spesies Liriomyza yang menyarang tanaman bawang daun, menunjukkan satu helai bawang daun dapat diserang oleh L. chinesnis dan L. huidobrensis. Namun populasinya masih didominasi oleh spesies $L$. huidobrensis, yang menjadi ancaman besar terhadap kerusakan bawang daun.

C. horticola merupakan spesies lalat lalat pengorok daun yang hanya menyerang tanaman kacang kapri. Hama $C$. horticola telah sejak lama ada di Indonesia dan telah menimbulkan kerugian besar tanaman kacang kapri (Kalshoven 1981). Namun sejak keberadaan $L$. huidobrensis di Indonesia, tampaknya telah menggeser kedudukan C. horticola sebagai hama penting pada tanaman kapri. Serangan hama pengorok daun pada tanaman kacang kapri di Desa Ciloto Kecamatan Pacet, hampir semua spesies pengorok yang keluar dari daun kacang kapri adalah L. huidobrensis.

Dalam hubungan dengan parasitoid yang berassosiasi dengan lalat pengorok daun, ditemukan delapan spesies parasitoid yang terdiri atas tiga familia yaitu Eulophidae, Eucoilidae dan Braconidae. $H$. varicornis, A. deluchii, N. okazakii, N. formosa, Neochrysocharis sp., Q. liriomyzae adalah spesies dari familia Eulopidae. Sedangkan O. chromatomyiae adalah spesies dari familia Braconidae dan $G$. micromorpha adalah spesies dari familia Eucoilidae. Namun proporsi parasitoid didominasi oleh $H$. varicornis dan 0 . chromatomyiae. Survei yang dilakukan oleh Rauf \& Shepard (1999) menemukan delapan spesies parasitoid yang berassosiasi dengan lalat pengorok daun yang terdiri atas familia Eulopiodae dan Eucoilidae. Susilawati (2002) menemukan 19 speises parasitoid yang menyerang lalat pengorok daun di Daerah Bogor dan Banjar yang terdiri atas familia Eulopidae, Braconidae, dan Eucoilidae.

Dari delapan spesies parasitoid yang ditemukan, $H$. varicornis dan $O$. chromatomyiae merupakan parasitoid yang paling mendominasi di lapangan. Kedua spesies tersebut merupakan parasitoid yang dominan pada dataran tinggi ( Hidrayani 2003; Purnomo 2003). $H$. varicornis menempati proporsi paling tinggi ( $\pm 88 \%$ ) 
pada skala ketinggian 700-1000 m dpl, sedangkan dengan peningkatan ketinggian tempat dari permukaan laut proporsi $H$. varicornis menurun dan terjadi peningkatan pada proporsi $O$. chromatonmyiae dari $2 \%$ pada skala $700-1000 \mathrm{~m}$ dpl menjadi $40 \%$ pada skala 1301-1600. O. chromatomyiae lebih sesuai hidupnya pada daerah yang lebih tinggi dari permukaan laut. Proporsi parasitoid lainnya hanya mencapai kisaran maksimal 4\%.

Tingkat parasitisasi parasitoid pada berbagai jenis tanaman sayuran berkisar dari 6,25 sampai 62,91\%. Tingkat parasitisasi demikian diharapkan dapat efektif menekan populasi lalat pengorok daun di lapangan karena keragaman parasitoid yang cukup tinggi. $O$. chromatomyiaejuga dapat menginfasi tanaman bawang daun, namun tingkat parasitisasinya masih rendah $( \pm$ $6 \%$ ), sedangkan pada tanaman caisim dan selada cukup tinggi masing-masing $45 \%$ dan $62 \%$. Keberadaan parasitoid yang dominan ini berlimpah di lapangan dapat meningkatkan jumlah kematian lalat pengorok daun.

\section{KESIMPULAN}

Tanaman sayuran dataran tinggi Kabupaten Cianjur dan Bogor telah diinfasi oleh empat spesies lalat pengorok daun, yakni $L$. huidobrensis, $L$. sativae, $L$. chinensis dan $C$. horticola. Dua spesies pertama, $L$. huidobrneisis dan L. sativae bersifat polifag sedangkan L. chinensis dan C. horticolabersifat monofag masingmasing pada tanaman bawang (Alliumsp.) dan kacang kapri (Pisum sativum).

Hasil pengamatan terhadap pertanaman sayuran dataran tinggi menunjukkan bahwa terdapat delapan spesies parasitoid yang berassosiasi dengan larva lalat pengorok daun yang terdiri dari familia Eulopidae, Braconidae dan Eucoilidae. Kedelapan spesies tersebut adalah $H$. varicornis, $A$. deluchii, N. okazakii, $N$. formosa, Neocrhysocharis sp. Q. liriomyzae (Eulopidae), O. chromatomyiae (Braconidae), dan G. micromorpha (Eucoilidae). O. chromatomyiae dapat menyerang lalat pengorok daun yang menginfasi semua spesies tanaman yang dikoleksi dengan tingkat parasitisasi mencapai 62,26\%.

Semakin tinggi ketinggian tempat dari permukaan laut jumlah L. huidobrensis semakin berlimpah. Demikian juga komposisi $O$. chromatomyiae semakin berlimpah dengan semakin tinggi daerah dari permukaan laut.

\section{UCAPAN TERIMA KASIH}

Penelitian ini merupakan bagian dari Penelitian Hibah Bersaing, Direktorat Jenderal Pendidikan Tinggi, Departemen Pendidikan Nasional Tahun Anggaran 2007 pada Lembaga Penelitian, Universitas Riau. Kami mengucapkan terima kasih atas bantuan hibah yang telah diberikan. Ucapan terima kasih juga kami sampaikan kepada Bapak DR. Rosichon Ubaidillah dari Museum Serangga, Lembaga IImu Pengetahun Indonesia (LIPI) atas bantuan identifikasi ulang terhadap spesimen parasitoid.

\section{DAFTAR PUSTAKA}

Cardova C \& Karel AK. 1990. Insect and other invertebrate pest of beans. In S.R. Singh. Insect Pest of Food Legumes. Jhon Willey \& Sons Ltd. 157-191.

Fisher N, Ubaidillah R, Reina P, La Salle J. 2006. Liriomyza Parasitoids of South East Asia. Australia

Herlinda S, Purwanti E, Pujiastuti Y, Rauf A. 2006. Preferensi Liriomyza sativae (Blanchard) (Diptera: Agromyzidae) pada ketimun dan tomat. Agritop 25(1): 7-11.

Hidrayani. 2003. Bioekologi Hemiptarsenus varicornis (Girault)(Hymenoptera: Eulopidae), parasitoid Liriomyza huidobrensis (Blanchard) (Dipetara:Agromyzidae) (Diptera: Agromyzidae). Disertasi. Bogor: Institut Pertanian Bogor.

Johnson MW. 1993. Biological control of Liriomyza leafminers in the Pasific Basin. Micronesia 4:81-92

Kalshoven LGE. 1981. The pest of Crop in Indonesia. Revised by PA. van der Laan. Jakarta: PT. Ichtiar Baru. Van Hoeve.

Murphy ST \& LaSalle J. 1999. Balancing biological control strategies in the IPM of new world invasive Liriomyza leafminers in field vegetable crops. Biocontrol News and Information 20: 91-104.

Parella MP. 1987. Biology of Liriomyza. Annu Rev Entomol 32:201-224

Parella MP. 1982. A reviev of history and taxonomy of economically important serpentine leafminers (Liriomyza spp.) in California (Diptera: Agromyzidae). Pan Pac Entomol 58:302-308.

Purnomo. 2003. Liriomyza huidobrensis (Blanchard) (Diptera; Agromyzidae): Kesesuaian inang, perkembangan populasi, dan pengaruh insektisida translamina. Disertasi. Bogor: Institut Pertanian Bogor.

Rauf A. 1995. Liriomyza: hama pendatang baru di Indonesia. Bul Hama dan Penyakit Tumbuhan 8(1): 46 - 48.

Rauf A. 1999. Persepsi dan tindakan petani kentang terhadap lalat pengorok daun, Liriomyza huidobrensis (Blanchard) (Diptera: Agromyzidae). Bul Hama dan Penyakit Tumbuhan 11(1): 1-13.

Rauf A, Shepard BM. 1999. Leafminers in vegetables in Indonesia: surveys of host crops. Species composition, parasitoids and control practices. Worhshop of Leafminers of Vegetables in Southeast Asia. Selangor, 2-5 February 1999. Selangor: $C A B$ International, Southeast Asia Regional Center.

Rauf A, Shepard BM. 2001. Current status on the biology, ecology and management of Liriomyza spp. in Indonesia with emphasis on L. huidobrensis. Paper presented at Seminar on Invasive Arthropod Pests of Vegetables and Economic Food Crops. Kualalumpur Malaysia, 13-14 March 2001. 
Rauf A, Shepard BM, Johnson MW. 2000. Leafminers in vegetables, ornamental plants and weeds in Indonesia: surveys of host crops, species compositio and parasitoids. Intern J Pest Manage 46(4): 257 - 266.

Rustam R. 2002. Biologi Opius sp.(Hymenoptera: Braconidae) parasitoid lalat pengorok daun kentang. Tesis Pasca Sarjana. Bogor: IPB.

Spencer KA. 1973. Agromyzidae (Diptera) of Economic Importance. Dr. W Junk BV. The Hague, $418 \mathrm{p}$.
Spencer KA, Steyskal BC. 1986. Manual oh the Agromyzidae (Diptera) of United States. New York: USDA.

Setiawati W. 1998. Liriomyza huidobrensis hama baru pada tanaman kentang. Bandung: Balai Tanaman Sayuran.

Supartha IW. 1998. Bionomi lalat pengorok daun, Liriomyza huidobrensis (Blanchard) (Diptera: Agromyzidae), pada pertanaman kentang. Disertasi. Bogor: IPB.

Susilawati. 2002. Komposisi dan kelimpahan parasitoid lalat pengorok daun Liriomyza sativae Blanchard (Diptera: Agromyzidae). Tesis Pasca Sarjana. Bogor: IPB. 